\title{
Temporal Cities: Commemoration at Manzanar, California and Cowra, Australia
}

\author{
Lynne Horiuchi \\ Independent scholar, Oakland, CA, USA \\ clhoriuchi@gmail.com \\ Anoma Pieris \\ Melbourne School of Design, University of Melbourne, Melbourne, Australia \\ apieris@unimelb.edu.au
}

\begin{abstract}
This article compares two former Pacific War incarceration histories in the us and Australia, inquiring how their narratives of confinement and redress might be interpreted spatially and materially, and how these sensibilities are incorporated into contemporary heritage strategies including, in these examples, through Japanese garden designs. At the Manzanar Historic Site in California, the efforts of several generations advocating for civil rights and preservation of the Manzanar Relocation Center have overlapped with the National Park Service's efforts to fulfil its federal mandates to preserve and restore the historic site. Conversely at Cowra, New South Wales, these histories are interwoven with post-war commemorative spaces, aimed at drawing visitors to former incarceration sites and encouraging contemplation of these difficult histories. This article analyses their complex creative processes and interpretive strategies as useful for drawing these isolated national stories into broader global interrogations of their significance.
\end{abstract}

\section{Keywords}

Commemoration - Japanese gardens - Japanese American internment - Australia-Japan Cowra breakout - Manzanar

* Funding for this collaborative research was provided by an Australian Research Council Future Fellowship FT14010019o award to Anoma Pieris and a visiting scholar position for Lynne Horiuchi at the University of Melbourne. 


\section{Introduction}

This article compares two former Pacific War incarceration histories in the us and Australia, inquiring how their narratives of confinement and redress are incorporated into contemporary heritage strategies. These strategies are related to very different physical sites and conditions over time, and the essay is anchored in three pervasive themes of nationalism, violence, and memory with their physical manifestations intensified under conditions of war. It anticipates topics analysing the hegemonic, defensive, and human dimensions of conflict and resultant transnational mobilities. We have selected the two most prominent commemorative sites in the respective nations, demonstrating how in each case stories of incarceration prompt very different narratives of reconciliation. We adopt the lens of spatial planning, architecture, and landscape practice to evaluate place-specific commemorative strategies at these sites, where landscapes have been physically configured through development, erasure, and commemoration.

Because planning and architecture were central to creating physical landscapes that confine and isolate prison populations, spatial analysis is implicit in the examination of material planning and design of spaces with the attendant characteristics of modes of control, discipline, and surveillance identified in foundational texts by theorists such as Michel Foucault and Giorgio Agamben. ${ }^{1}$ These landscapes subsequently served for the recuperation and commemoration of that confinement, which - in tandem with evidence of agency in the creation of physical spaces within the camps - may be seen to counter the dominant state oppression of wartime military power, violence, and incarceration in these two settler nations, the us and Australia.

Our exploration here is a preliminary account related to a larger project being developed to reveal the physical and linked characteristics of globalized incarceration during World War II. Our specific interest is in developing a transpacific approach collaboratively that might prove useful for understanding how the geopolitical positions and immigration histories of these

1 As scholars of prison environments have noted, Michel Foucault (Discipline and Punish: The Birth of the Prison, trans. Alan Sheridan, New York: Pantheon Books, 1977; Power/Knowledge: Selected Interviews and Other Writings, 1972-1977, trans. Colin Gordon, New York: Pantheon Books, 1980) and Agamben continue to influence theoretical and spatial approaches to confinement. See Giorgio Agamben, State of Exception (Chicago: University of Chicago Press, 2005), which has been used broadly to engage discussions of spaces of confinement instituted outside of normative rule of law or martial law, and Dominique Moran, Carceral Geography: Spaces and Practices of Incarceration (Farnham: Ashgate Publishing, 2015), 17-28. 
two nations produced very different readings of incarceration and national enemies, although their troops fought side by side during the Pacific War (1941-1945). This article provides an overview of the wartime deployment of architectural and urban expertise for military mobilisation, POW incarceration, and civilian internment; and following the war, for post-war reconstruction and resettlement, celebration, and commemoration-rich and diverse landscapes in these two nations yet to be fully explored comparatively. A comparative view allows for an exploration expanding the national focus of the study of these sites to create a more balanced understanding of the interconnections of wartime architecture, commemoration, and recent global trends in Asia Pacific studies. ${ }^{2}$

National histories have provided limited insights into wartime incarceration's lasting international impacts, and the relatively new phenomenon of linking interests in Asian American, Asian, and American studies has directed little attention to material and ontological history, which has the capability of illuminating lives entangled daily in imperial conflicts. Conceived in the spirit of recent scholarship on the wartime involvement of architects, this essay seeks to draw incarceration histories into an already complex global field of Pacific War Studies. ${ }^{3}$ Following from previous global studies presenting commentaries on contemporary scholarship studying "empires" in the Pacific, ${ }^{4}$ this paper proposes a dialogic transnational discourse across Asia, America, and Australia focusing on the incarceration of culturally Japanese subjects, whether civilian internees (in the USA) or prisoners of war (in Australia). ${ }^{5}$

2 Typically examined through military records or memoirs, the spatial, material and architectural realities of the 1942-1945 Pacific War have been neglected, despite the enormous consequences for defining and spatializing post-war citizenship in Australia and America. Whereas the war in the Atlantic has invited extensive research on war-related construction and commemoration, animated by the 7oth anniversary celebrations of the war's end (2015), histories of the Pacific War are relatively muted.

3 Most notably Jean-Louis Cohen, Architecture in Uniform: Designing and Building for the Second World War (Montreal: The Canadian Centre for Architecture, 2011); on memorializing dissonant heritage, William Logan and Keir Reeves, Places of Pain and Shame: Dealing with "Difficult Heritage" (London and New York: Routledge, 2009); and on material and social memories, T. Fujitani, Geoffrey M. White, and Lisa Yoneyama (eds), Perilous Memories: The Asia-Pacific War(s) (Durham: Duke University Press, 2001).

4 For example, Eiichiro Azuma, Between Two Empires: Race, History, and Transnationalism in Japanese America (New York: Oxford University Press, 2005), Kay Saunders and Roger Daniels (eds), Alien Justice: Wartime Internment in Australia and North America (Brisbane: University of Queensland Press, 200o); and Karen J. Leong and Myla Vicenti Carpio (eds), "Carceral States" (special issue), Amerasia 42, no. 1 (2016).

5 For a review of a conversion of interests among historians of the American West, Hawai'i, and the Pacific Islands, of Asian Americans, and of the Japanese and American empires, 
While politically distinct from one another, the camps designed for their incarceration shared similar punitive attributes.

\section{Two Typologies}

In the us, the military's creation of the Manzanar Relocation Center site, intended to hold civilians of both Japanese and American citizenship residing on the West Coast, Alaska, and parts of Arizona, was authorized through a Presidential Executive Order 9066 (Eo 9o66) issued by President Franklin D. Roosevelt on 19 February 1942. Justified as a military necessity, "people of Japanese ancestry" were identified as potential saboteurs, spies, and a threat to national security, allowing for the mass incarceration, with no charges or due process, of whole communities and families-all civilians. This was not only an abrogation of their rights as citizens; it resulted in the nearly complete disenfranchisement of this population. ${ }^{6}$ While other internment sites were created to manage "alien individuals" arrested and incarcerated on an individual basis by the Federal Bureau of Investigation (FBI), the Army, and the Immigration and Naturalization Service (INS), EO 9066 is generally recognized as an abrogation of American constitutional rights. ${ }^{7}$ Because the Japanese American community carried out a successful campaign for redress and Eo 9066 became an important adjudicated civil rights dispute, the commemoration of the Manzanar site has focused on issues of American civil liberties and the flexible liberality

see Jordan Sand, "Reconfiguring Pacific History: Reflections from the Pacific Empires Working Group," Amerasia 42, no. 3 (2016): 1-41.

6 Those incarcerated under Eo 9066 were eventually freed through a Supreme Court habeas corpus decision on 17 December 1944, Endo vs. Us. See Greg Robinson, Tragedy of Democracy: Japanese Confinement in North America (New York, Columbia University Press, 2001), 35, 55. See Also Greg Robinson and Toni Robinson, "Korematsu' and Beyond: Japanese Americans and the Origins of Strict Scrutiny," Law and Contemporary Problems 68, no. 2 (2005): 29-55; Patrick O. Gudridge, “Remember Endo?" Harvard Law Review 116 (2003): 1933-1970.

7 EO 9066 has not been found unconstitutional. Although Judge Marilyn Patel of the Us District Court could not reverse a Supreme Court decision in the case of Fred Korematsu, she noted that, "As a historical precedent it stands as a constant caution in times of war or declared military necessity our institutions must be vigilant in protecting constitutional guarantees," and she granted a writ of coram nobis vacating his case based on prosecutorial misconduct in misrepresenting evidence for military necessity and suppressing information that should have been presented to the Supreme Court. Roger Daniels, The Japanese American Cases: The Rule of Law in Time of War (Lawrence, Kansas: University of Kansas Press, 2013), 172-173. 
of American rule of law, now designated a national park in order to preserve the site and to interpret the injustices of the incarceration.

In Australia, Camp No. 12 at Cowra, New South Wales, was a military prisoner of war (POW) camp created under the jurisdiction of the National Security Act of 1939, in accordance with Australia's interpretations of the provisions for prisoners of war under the Geneva Convention. Cowra was one among eight major Pow and internment camp complexes (there were eighteen camps in total) distributed across Australia's southeastern states, far away from sensitive areas in the nation's north, most vulnerable to attack by the Japanese forces. ${ }^{8}$ In the camps that acted as remote prisons for Britain's pows and held pows taken during Pacific battles, Australia interned both resident and non-resident enemy nationals. ${ }^{9}$ These camps were mechanisms for sorting and understanding the national alliances of imperial competitors from the viewpoint of a nation simultaneously caught up in two theatres of conflict-one of them too remote to be threatening, and the other at its border, yet with their separate alignments and associated anxieties-conjoined in the Australian camp demographic.

At the Manzanar Historic Site in California, located $35^{\circ}$ kilometres north of Los Angeles in the Owens River Valley, the efforts of several generations advocating for civil rights and the preservation of the Manzanar Relocation Center site have overlapped with the National Park Service's efforts to fulfil its federal mandate to create a nationally focused remembrance of the confinement. In comparison, at Cowra, a small town 188 kilometres north of Canberra, postwar commemorative spaces of international dimensions aim to draw both local and overseas visitors (including from Japan) to former incarceration sites and encourage contemplation of these difficult histories.

Neither site was constructed for the purpose of evacuating displaced people from an area affected by a natural disaster, flight from war-torn areas, or mass migration from economically devastated areas, but were instead part of military plans to construct sites for imprisonment and confinement in the Pacific Rim from 1942 to 1945, during World War II. While similarities may be seen

8 Australian Government Federal Register of Legislation, "National Security Act 1939," 9 September 1939, https://www.legislation.gov.au/Details/C1939Aooo15. Camps were established at Cowra, Hay, and Holsworthy in New South Wales; at Enoggera in Queensland; at Harvey and Rottnest Island in Western Australia; at Loveday in South Australia; and at Tatura in Victoria.

9 Britain requested that Commonwealth Countries receive up to 50,000 prisoners and Australia agreed on 3 July 1940. National Archives Australia, Canberra: A2671, 157/1940 PART 1, War Cabinet Agendum — No. 157/1940—Prisoners of War and internees from abroad. This was later reduced to 12,000 . 
in the design and construction of the prison camps, the purpose and post-war commemoration of Manzanar and Cowra differ in form, focus, community involvement, and international networks.

\section{Comparison of Physical Sites Developed during World War II}

\section{1 \\ The Manzanar Relocation Center}

The euphemistically named Manzanar Relocation Center was one of ten semipermanent prison camps the us government used to incarcerate approximately 110,000 people, sited in isolated rural areas and built under EO 9066 with the full cooperation of numerous New Deal agencies (fig. 1). ${ }^{10}$ Like Cowra, the Manzanar site bears the stamp of military development, although in a more

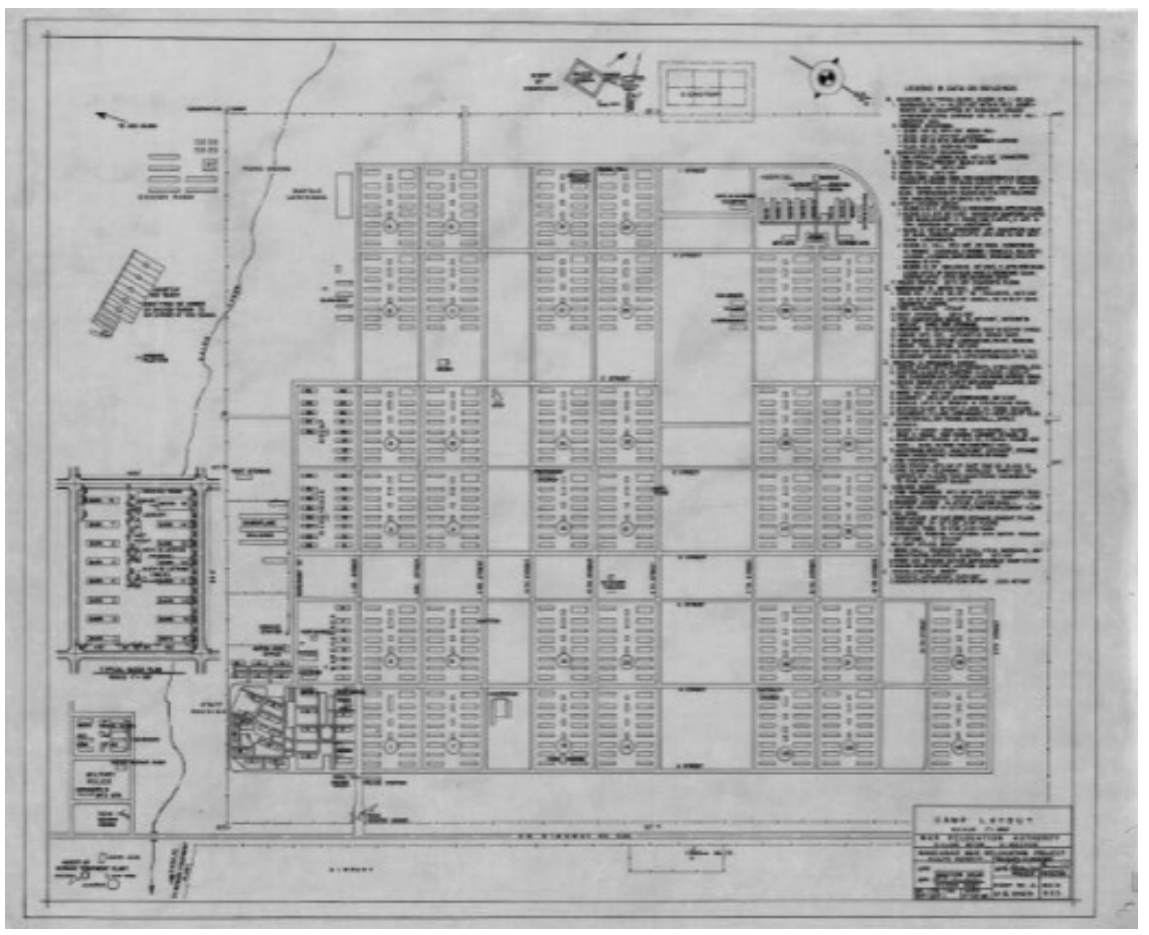

FIgURE 1 California, Manzanar, Camp Layout (Sheet 1 of 6). War Relocation Authority, 20 April 1946, National Archives and Records Administration, Record Group 210, Cartography, College Park (public record).

10 The numbers vary as the action involved the continuous movement of people. See "Personal Justice Denied: Report of the Commission on Wartime Relocation and Internment 
rigid, gridded structure, and on a larger scale. Planned by the us Army Corps of Engineers (The Corps) using standard schematic layouts and block plans, the sites materially express a normative efficient monotonous landscape of control and order. The Center was a racially segregated city as well as a source of indentured labour used for the subjugation and cultivation of agricultural land, war-related industries, harvesting sugar beets, camouflaging net factories, and constructing irrigation works, among other examples. ${ }^{11}$

The Corps began construction of the Manzanar Relocation Center on 21 March 1942. The Army had leased 2,510 hectares of land from the Los Angeles Department of Water and Power, of which 98 hectares were later dedicated to agricultural production; they then created a 210 -hectare grid that served as the organizational, social, and political units for the prison city, designed for a maximum population of 10,800. Each block housed approximately 300 people using basic communal military facilities-barracks, mess halls, latrines, and laundries. In the prisoners' residential areas, basic urban infrastructure was furnished with hospital facilities, roadways with sewage and water utilities running the length of the blocks' cores to the mess halls, latrines, and laundries, with electrical service only in the barracks units, and one water tap per barrack. The Corps arranged separate compounds for administration, staff housing, warehouses, military police, and maintenance functions on the perimeter of the prisoners' residential areas. ${ }^{12}$

Aerial photographs and architectural drawings and plans are types of tools architectural historians often employ for understanding the material

of Civilians," United States Commission on Wartime, Relocation, and Internment of Civilians (CWRIC) (Seattle: University of Washington Press; Washington, DC: Civil Liberties Public Education Fund, 1997), 3 and Tetsuden Kashima, Judgment without Trial:Japanese American Imprisonment During World War II (Seattle: University of Washington Press, 2003), 104-106. Additionally, as many as 17,000 other Japanese "enemy aliens" residing in the us mainland, Hawai'i, Alaska, the Marshall Islands, and Latin America were interned in more than sixty-five other facilities, along with German and Italian enemy aliens considered threats to American national security, with arrests beginning immediately following the Japanese attack on Pearl Harbor (7 December 1942).

11 "Suggested Resettlement or Work Projects," April 1942, Box 1, Records of the Bureau of Agriculture Economics, Record Group 83, National Archives and Records Administration at San Francisco, San Bruno, CA, USA. See also Colleen Lye, America's Asia: Racial Form and American Literature, 1893-1945 (Princeton: Princeton University Press, 2005), 141-203.

12 See Jeffrey F. Burton et al., Confinement and Ethnicity: An Overview of World War II Japanese American Relocation Sites (Tucson: Western Archaeological and Conservation Center, 1999), 40-45, 160-202. See also Lynne Horiuchi, "Dislocations and Relocations: The Built Environments of Japanese American Internment," Ph.D dissertation, University of California, Santa Barbara, 2005. 
construction of spaces such as Manzanar. As progressive modes for efficient construction, these tools reflect the military's attempt to establish normative hegemonic control and rational order through material design, but reveal little about the disheartening, inadequate, and chaotic living conditions within the camps, especially during the first months of occupation. The incarcerated population had to deal with the initial shock and dehumanizing effect of their nearly complete disenfranchisement. The barracks were built with green wood that soon shrank in the dry environment, leaving large cracks that failed to keep out inclement weather or dust. Before the sewage system was completed, open sewers were common, the inadequate toilet and shower facilities lacked privacy, and prisoners had to wait in long lines to access communal spaces, including the mess halls with nearly inedible food.

In order to understand the agency, mobility, and community life of populations who have experienced mass incarceration, over the last two decades scholars of American architecture and American Studies have developed alternative methodologies that may be used to study the cultural material of the everyday lives of prisoners. ${ }^{13}$ These methodologies have developed in tandem with postcolonial studies of subaltern sites with wide-ranging applications, for example, from colonial and imperial uses of unfree labour to internal colonization of Indigenous populations. ${ }^{14}$ In cultural material studies, American

13 Post-construction occupancy analysis is a useful way for understanding the transition between sites, habitation, and reuse that tells us more from the prisoners' perspective about their everyday use of space and buildings, and the intensive production of scholarly work on this mass incarceration provides rich troves for fleshing out the material culture along with oral histories, personal archives, anthropological studies, and the preservation of vast stores of government archives. For example, the study of the Japanese American mass incarceration is one of the most developed historiographies in Asian American studies.

14 Architectural theory relating to work on migration, ethnic, and racial difference engages extremely diverse terms of framing, location, and interdisciplinary interests. Approaches to such topics as race, ethnicity, national belonging, modernity in post-colonial subjectivity, and migration are often very different depending upon national-regional (or topical) starting points, and crossovers in fields of study that have previously operated relatively separately. Some works, such as Craig L. Wilkins' The Aesthetics of Equity: Notes on Race, Space, Architecture, and Music (Minneapolis: University of Minnesota Press, 2007), focus specifically on architectural theory, while others-particularly collections of essaysattempt to expand cross-disciplinary work, such as C. Greig Crysler, Stephen Cairns, and Hilde Heynen (eds), The SAGE Handbook of Architectural Theory (London: SAGE Publications Inc., 2012); Duanfang Lu (ed), Third World Modernism: Architecture, Development and Identity (London and New York: Routledge, 2011); Arijit Sen and Jennifer Johung (eds), Landscapes of Mobility: Culture, Politics and Placemaking, (London and New York: Routledge, 2013); Beth Tauke, Korydon Smith, and Charles Davis (eds), Diversity in Design: 
vernacular architectural historians-drawing from historic archaeology, historic preservation, and contemporary theory of everyday life-have created methodologies for producing knowledge about common places and architecture that are not iconic. ${ }^{15}$ For example, Arijit Sen and Jennifer Johung have developed landscapes as a concept to interrogate the material culture that constitutes "elements, buildings, ecologies, fields, boundaries and edges, people, cultures and movement that make up certain spatial territories." 16

In this vein, Kenneth Helphand's examination of the creation of gardens during times of war is an example of this movement toward expanding the contexts of buildings and landscapes, useful for understanding the wartime gardens at the Manzanar Relocation Center as "defiant gardens" that, on the one hand, were "created in extreme or difficult environmental, social, political, economic, or cultural conditions" and, on the other hand, "represent adaptation to challenging circumstances (...) also viewed from other dimensions as sites of assertion and affirmation."17 In the latter mode, from the moment Manzanar "opened" on 21 March 1942, incarcerated residents from a broad spectrum of previous occupations - gardeners, landscapers, cut-flower growers, shopkeepers, merchants, farmers, mechanics, doctors, nurses, and many more-worked intensely on private projects intended to improve and beautify their living environments. In July 1942, a War Relocation Authority (WRA) report noted there were some "300 Victory Gardens, 100 lawns greening between tar paper barracks (...) gardens of rocks, cacti, miniature lakes, restive-decorative porches and tree stumps and roots fashioned into bird, animal and snake caricatures."18 Professional landscape architects Tom Takaki and Nobuo Kawabata devised

Understanding Hidden Consequences, (Abingdon and New York: Routledge, 2016); Mrinalini Rajagopalan and Madhuri Desai (eds), Colonial Frames, Nationalist Histories: Imperial Legacies, Architecture, and Modernity (Farnham: Ashgate Publishing, 2012).

15 See Dell Upton and John Michael Vlach (eds), Common Places: Readings in American Vernacular Architecture (Athens: University of Georgia Press, 1986) and Dell Upton, Another City: Urban Life and Urban Spaces in the New American Republic (New Haven: Yale University Press, 2008), as well as many articles by Upton on topics such as the material culture of the city, soundscapes, and the architecture of everyday life. See also the publications of the Vernacular Architectural Forum.

16 See Sen and Johung, introduction to Landscapes of Mobility, 1-17 for theoretical framing for this concept.

17 Kenneth I. Helphand, Defiant Gardens: Making Gardens in Wartime (San Antonio: Trinity University Press, 2006), 1.

18 "Summary Report on Center Requested by Dr. Carter, 24 July 1942," Japanese Evacuation and Resettlement Study from Bancroft Library, Drawer Manz I, Folder "Official Documents," Eastern California Museum, Independence, CA, USA. 
comprehensive beautification plans that included mini-parks for each housing block, which may have been inspired by the Farm Security Administration (FSA) community plans drawn by Garrett Eckbo and Vernon DeMars, internationally renowned architects from the FSA's San Francisco office. ${ }^{19}$

Idyllic and utopian, Kango Takamura's watercolour work Saturday Afternoon Looking South from Block 8 (May 1943) provides a record of a landscape that would seem to validate both Helphand's concept of a "defiant garden" and the WRA's vision of a peaceful American city_ironically at liberty to enjoy their public parks - with neatly kept gardens where children play and people enjoy other leisurely Saturday afternoon activities (fig. 2). ${ }^{20}$ Takamura celebrates the field of green grass and what appears to be a formal garden with a substantial border. He visually catalogued the beautification (and practical) projects devised to make the public space enjoyable: trash cans for litter, flower gardens

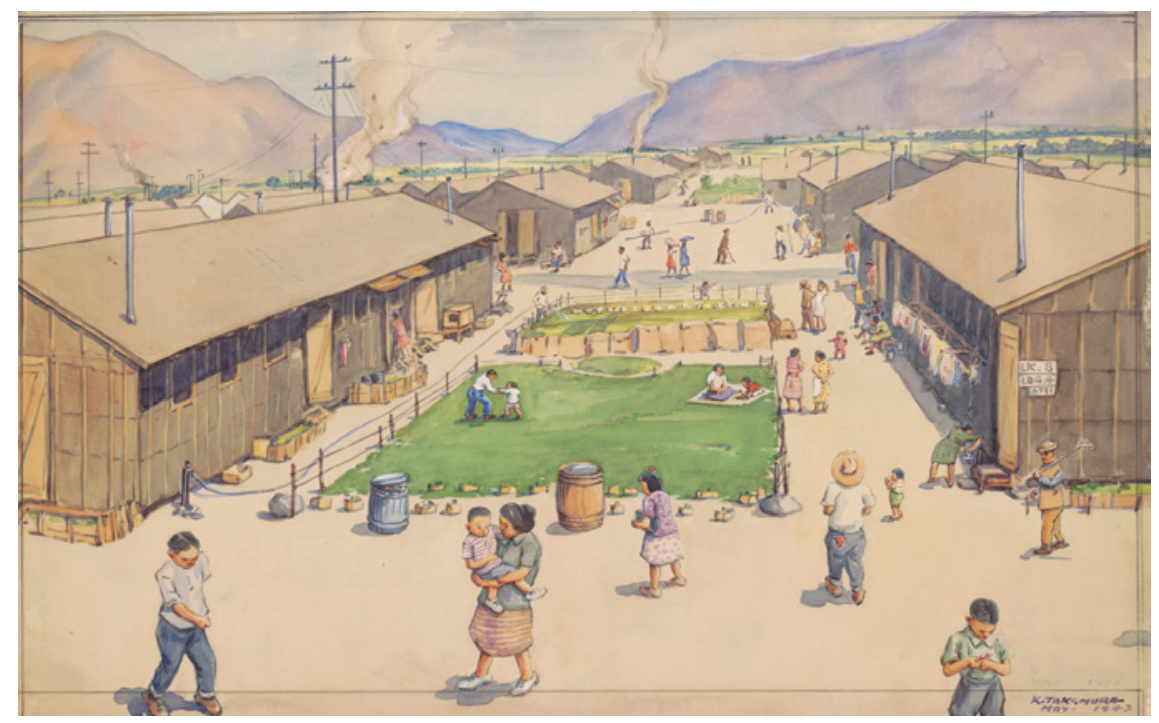

FIGURE 2 Kango Takamura, Saturday Afternoon Looking South from Block 8, May 1943, University of California Los Angeles Special Collections, Collection 433, Box 1 Manzanar, F.16. Los Angeles, CA, USA.

19 Helphand, Defiant Gardens, 171. For Garret Eckbo and Vernon DeMars' FSA community planning for the prison cities, see Caroline Constant, The Modern Architectural Landscape (Minneapolis: University of Minnesota Press, 2012), 125-127 and Lynne Horiuchi, "Architects at War: Designing Prison Cities for Japanese American Communities," in Diversity and Design: Understanding the Hidden Consequences, ed. Beth Tauke, Korydon Smith, and Charles Davis, 101-117 (New York: Routledge, 2016).

20 Kango Takamura, "Saturday Afternoon Looking South from Block 8," May 1943, UCLA Special Collections, Collection 433, Box 1 Manzanar, F.16. 
around the barrack doors, benches, planted borders along the sidewalks, a clothes line installed on the barrack wall-a representation of a precious inter-barrack mini-park that sustained the mundane tasks of daily life in the prison city. It also seems to represent the ideal garden paradise associated with formal American "Main Street" parks and imagery, which contrasts with the larger Japanese-inspired public gardens at Manzanar photographed by Ansel Adams and Toyo Miyatake. Takamura seems to have thought of these peaceful parks as home, naming one of his paintings depicting agricultural workers returning to Manzanar from a sugar beet harvest work Home Sweet Home (1942).

In an oral history recorded by Deborah Gesensway and Mindy Roseman, Takamura spoke to his belief that leisure and cultural activities—enjoying the natural beauty of the camp site, celebrating the Japanese New Year mochizuki (rice pounding) ceremony, working on a children's museum, or painting, for example-helped the community forget their wartime dilemmas. ${ }^{21}$ Although he had to physically defend his daughter and her family when anti-wRA rioters attacked them, he addressed national loyalties in nuanced ways, speaking sympathetically about the pro-Japanese bravado of the kibei (American-born generation) and those educated in Japan who returned to the us as young adults (possibly to avoid conscription in the Japanese Army). He described his somewhat apolitical point of view as being a "quiet" person, and as a reasoned way of working through the difficult camp conditions without expressing explicit defiance of either pro-Japanese or pro-American political beliefs. His artistic sensibilities reflect resistance through community building as a mode to assert and affirm cohesion and to adapt to challenging circumstances.

Takamura's Untitled Winter Landscape seems to express the liminality and subjectivity of the Manzanar residents' diasporic lives (fig. 3). The mountain in the background, alight with alpenglow in the evening dusk, dominates the top section of the picture plane, with diminutive figures appearing suspended in the fog in the middle foreground over a section of land adjacent to the residential quadrant. The location of the Japanese American community's diaspora in this moment appears ephemeral and ontologically unstable, with no firm ground under the dispelling beauty of the Sierra Mountains.

These paintings by Takamura, as well as his extant oeuvre, represent activities and cultural material from both American and Japanese genres that question their relationship to American and Japanese imperialism, a topic now being explored in cross-disciplinary modes by scholars in Asian American

21 Deborah Gesensway and Mindy Roseman, Beyond Words: Images from America's Concentration Camps (Ithaca, NY: Cornell University Press, 1987), 117-113. See also Robinson, $A$ Tragedy of Democracy, 164-66. 


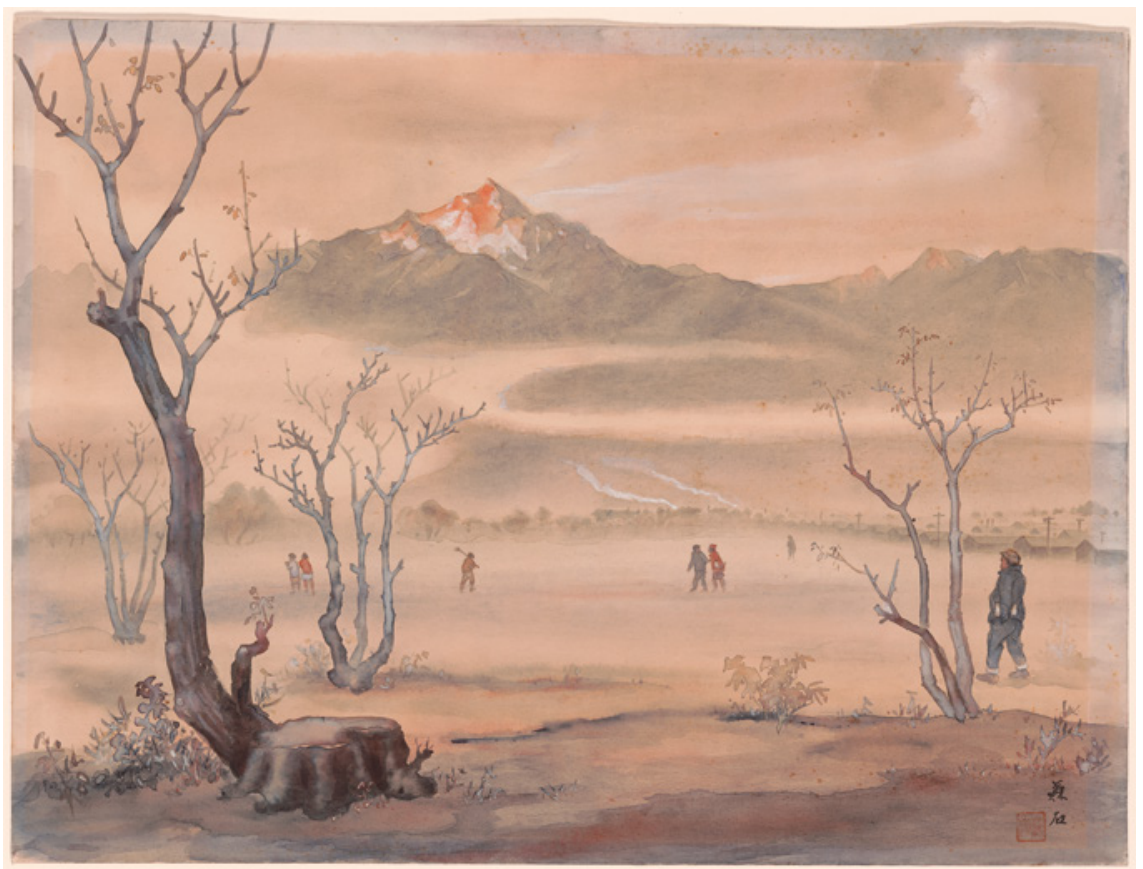

FIGURE 3 Kango Takamura, Untitled Winter Landscape, May 1943, University of California Los Angeles Special Collections, Collection 433, Box 3, Manzanar, F.2. Los Angeles, CA, USA.

and Asian studies. ${ }^{22}$ The comparison of the beautification projects within the Manzanar Relocation Center with wartime commemoration efforts in Cowra provides an opening point for understanding the Japanese mass incarceration within larger global diasporic movements, across national borders, and through the lens of multiple national loyalties or connections. Cowra may serve as a geographic magnet that links the mass incarceration there to the historical context of American colonization in Asia, as well as Japanese imperial colonization in Asia and Southeast Asia.

pow camps in Australia continued a historic legacy of penal colonies intended to contain and segregate Aboriginal populations, as well as of alien internment during World War I. These camps-constructed in each of the Australian

22 See essays from authors who participated in the Pacific Empires Working Group Forum and the Summer Institute in Asian American Studies Forum in Karen Leong and Myla Vicenti Carpio (eds), “Carceral States” (special issue), Amerasia 42, no. 3 (2016). 
states and typically related to military camp facilities built for 6,890 "enemy aliens" - were direct precedents for the World War II camps, which extended the practice to rural towns and the Pacific region. ${ }^{23}$ While at Cowra, government controls were aimed at preventing hostilities within groups of pows held in the same facility (e.g. fascist and anti-fascist amongst the Italians), efforts to control the Manzanar population were muddled, although there were real consequences for "troublemakers," such as confinement in Isolation Centers at Moab, Utah and Leupp, Arizona. At Manzanar, the WRA unevenly suppressed expressions of Japanese nationalism - at times violently-in favour of promoting American ideals, and internally the WRA/Us government exacerbated this within the prison population by using questionnaires to segregate individuals and families considered disloyal to the us. However, expressions of Japanese culture, rituals, and celebrations were tolerated within limits.

The Pow camp at Cowra was attached to a major military camp that trained 80,000 personnel and shaped the town's wartime identity. ${ }^{24}$ Australians were more intimately connected with the Pacific War, the military, and the Japanese due to the high proportion of the population involved in the conflict (10 per cent) and the direct threat to the continent. ${ }^{25}$ Air raids on Darwin and a submarine attack on the Sydney Harbour brought the war to Australia in 1942. Alongside Us troops in the Pacific, Australians fought the Japanese in Malaya, Southeast Asia, and New Guinea, and more than 22,00o Australian servicemen and women were taken captive. ${ }^{26}$ The Pow camp at Cowra represented a microcosm of Australia's colonial alliances and wartime engagements in Europe and Asia.

Unlike the rigid gridded template of the us Relocation Centers, camps in Australia varied according to size, use, and diversity of captives, combining different categories of prisoners in separate compounds of the same carceral complex. Their segregation was based on numerous factors, such as nationality, language, seniority (for service personnel), family status for civilians, and, later, following internal skirmishes between fascist and royalist factions, based

23 See the National Archives of Australia, "Wartime Internment Camps in Australia," http:// naa.gov.au/collection/snapshots/internment-camps/index.aspx\#sectionı and "World War I Internee, Alien and pow Records held in Adelaide—Fact sheet 106," http://naa.gov. $\mathrm{au} /$ collection/fact-sheets/fsio6.aspx.

24 Graham Apthorpe, A Town at War: Stories from Cowra in World War II (Cowra, Nsw: G. Apthorpe, 2008), 232.

25 Australian War Memorial, "Enlistment Statistics, Second World War," https://www.awm .gov.au/encyclopedia/enlistment/ww2.

26 Australian War Memorial, "Stolen Years: Australian Prisoners of War," https://www.awm .gov.au/exhibitions/stolenyears/ww2/japan. 
on political differences within the same nationality. Camp No. 12 incarcerated Italian civilians and Pows; Japanese Pows; Indonesian dissidents from Dutch colonies; and some Formosans (Taiwanese) and Koreans. Its population peaked at 4,6oo in 1946, a fair portion of the 25,727 Pows and 7,780 internees who would pass through the Australian camps. ${ }^{27}$ Some 1,104 of them were Japanese Pows. A comparable site in terms of population size and the incarceration of Japanese Pows would be the Pow camp at Honouliuli in Hawai'i.

Japanese civilians were not held at Cowra, but were incarcerated at Hay and Holsworthy (New South Wales), Loveday (South Australia), and Tatura (Victoria). Their numbers were far fewer than those in America, due the racialized structural exclusions of the settler colony. The White Australia Policy (1901-1973) had institutionalized the exclusion of non-white immigrants, preserving the homogeneity of European - and particularly Anglophoneculture, while structurally excluding Aboriginal populations across much of the twentieth century. Although certain industries-such as pearl fishing, sugar cane farming, and other service roles-exempted small groups of Japanese residents, they could not be naturalized. ${ }^{28}$ Consequently, a small, local population of 1,141 Japanese was filtered through northern and northeastern gaols and military camps to southern internment camps from 1941 onwards. ${ }^{29}$ Their numbers were augmented by 3,160 overseas internees, including Japanese residents of New Caledonia, New Hebrides, the Dutch East Indies, the Solomon Islands, and New Zealand. ${ }^{30}$ Japanese Pows from the Pacific Theatre formed a distinct group of 5,637 persons, whose cultural opacity to Australians heightened their group anxieties. Some 4,100 of this number were captured by us forces and handed over for custody. ${ }^{31}$

27 The Australian Army website, Documents and Training Materials, History of the Directorate of Prisoners of War, part 2, 106, https://www.army.gov.au/our-history/ primary-materials/post-war-and-korea-1946-to-1953/documents-training-materials. See also Apthorpe, A Town at War, 16-18; Joyce Hammond, Walls of Wire: Tatura, Rushworth, Murchison (Rushworth: Joyce Hammond, 1990), 9, following the National Security (Aliens Control) Regulations of 1939. History of the Directorate of Prisoners of War, 91.

28 In Australia, several acts aimed at restricting labour competition with Chinese and Pacific Islanders were introduced in 1901 and would become the basis for the White Australia policy, which restricted non-white immigration until 1973. A number of policies incrementally revised this stance.

29 Immigration from Japan was banned until the accommodation of war brides in 1949. See Yuriko Nagata, Unwanted Aliens (Brisbane: University of Queensland Press, 1996), 298.

$30 \quad$ Nagata, Unwanted Aliens, 298.

31 Australian Army website, History of the Directorate of Prisoners of War, part 2, 106. 
Details of detainee numbers and camp locations were withheld from the public for reasons of national security, and only the adjacent townspeople were aware of their presence. At Cowra, for example, the weekly movement of unfree Italian farm labourers made their presence known. ${ }^{32}$ No. 12 camp's size and design was unusual; it was one of three dodecagon designs where the military-regulation timber-framed huts with corrugated iron walls were arranged diagonally, as though radiating from the centre in a reversal of the panopticon plan (figs. 4-5). ${ }^{33}$ This plan was further quartered by the main thoroughfare-dubbed "Broadway" — and a firebreak deemed "No Man's Land." ${ }^{34}$ There were four separate 17-acre compounds for 1,000 persons each: two for Italians, one for Japanese officers, Formosans, and Koreans, and one for Japanese servicemen. Designed to accommodate forty-eight people dormitorystyle, the $60 \times 80$-foot ( 446 square metre) huts typically used in the Pow camps had corrugated iron walls ventilated by an approximately 8 -inch (20-centimetre) run of chicken wire under the eaves..$^{35}$ The external cladding and roofing were either galvanized iron or corrugated asbestos sheets.

Elsewhere in Australia, varied geometric figures such as rectangles, pentagons, and parallelograms were used to accommodate different configurations of prisoners and associated residential, utility, and military administrative facilities: fortifications and surveillance structures, temporary structures, landscape features, and camp-related agricultural areas and industries. Unlike at Manzanar, their designs were motivated not by the efficacy of a military grid but by the need to control prisoners with the fewest number of guard towers. Three barbed wire fences set 30 feet (9 metres) apart encircled the Cowra camp. ${ }^{36}$ The Commonwealth Disposals Commission auctioned all of these structures in March 1947 and the Department of Agriculture occupied the land in August 1948, leaving only the concrete-block foundations intact. ${ }^{37}$

Australia's attitude to its prisoners of war was one of deferred responsibility, as they were holding the prisoners for Britain and the Us. Their treatment

32 Apthorpe, A Town at War, 16.

33 Other formal arrangements included rectangles, parallelograms, and rhomboidal figures.

34 Jennifer Lambert Tracey and Michael MacLellan Tracey, "Archaeological Assessment of the Site of Prisoner of War Camp 12, Cowra, NSw. October 2003" (Canberra: Heritage Archaeology, 2003), 29-30.

35 New South Wales Office of Environment and Heritage, "Cowra Prisoner of War Camp Site," database number: 5045173, file number: S9o/oo661; S91/06355 \& HC870813. http:// www.environment.nsw.gov.au/heritageapp/ViewHeritageItemDetails.aspx?ID=5045173.

36 New South Wales Office of Environment and Heritage, "Cowra Prisoner of War Camp Site."

Tracey, Archaeological Assessment of Camp 12, 32. 


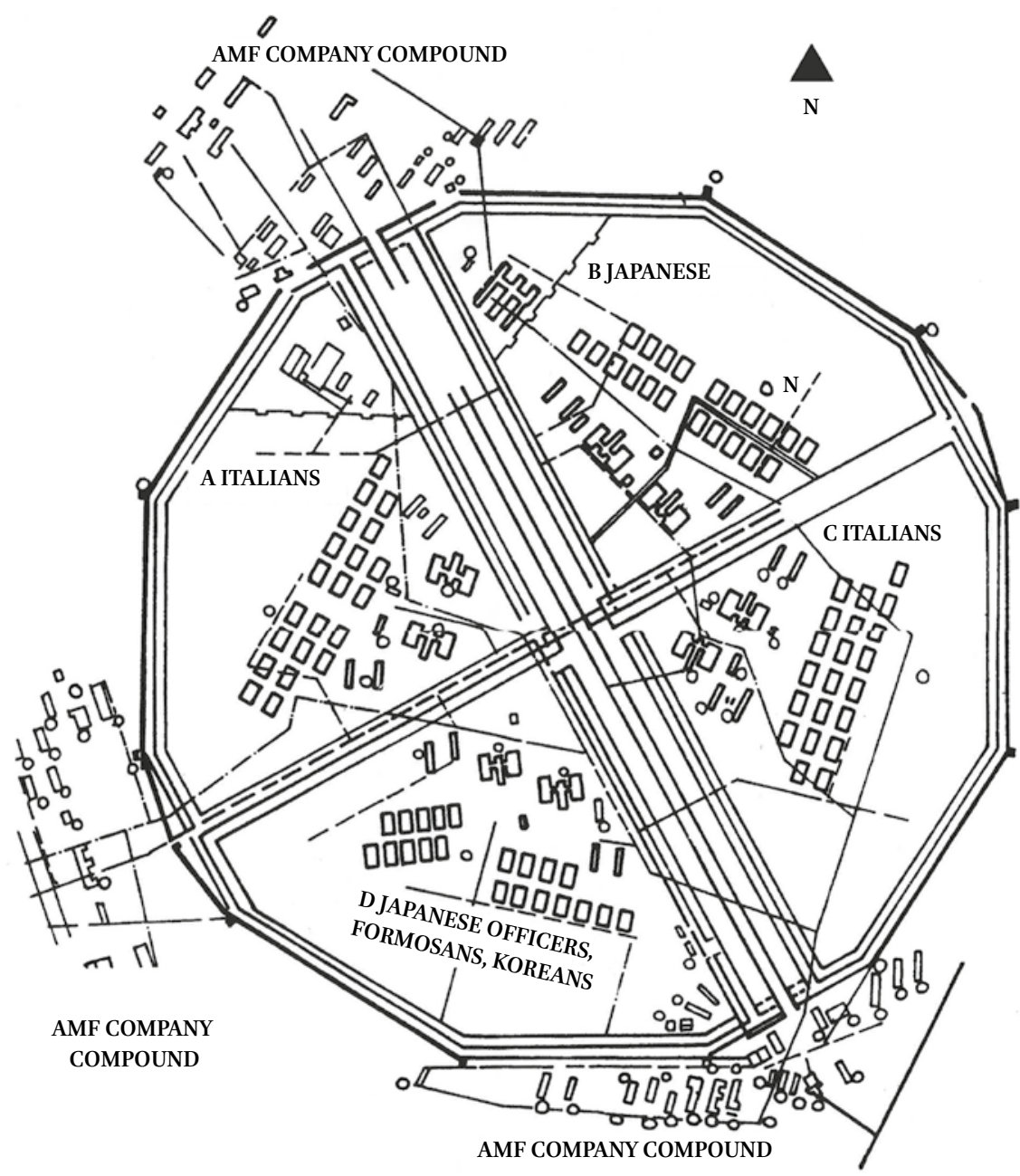

Cowra Township (3.2 Kms s.w.)

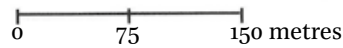

Layout of Cowra Prisoner of War Camp

FIgURE 4 Plan of Cowra Prisoner of War Camp No. 12. Provided by the Cowra Shire Council.

of prisoners was not excessively violent; rations were distributed liberally, with due regard to the Geneva Convention. Punishment comprised of everyday austerities, social and economic deprivation, the relentless routine of imprisonment, the remoteness of the geography, and the harshness of the semi-arid climate. While this did in many respects replicate a state of colonial 


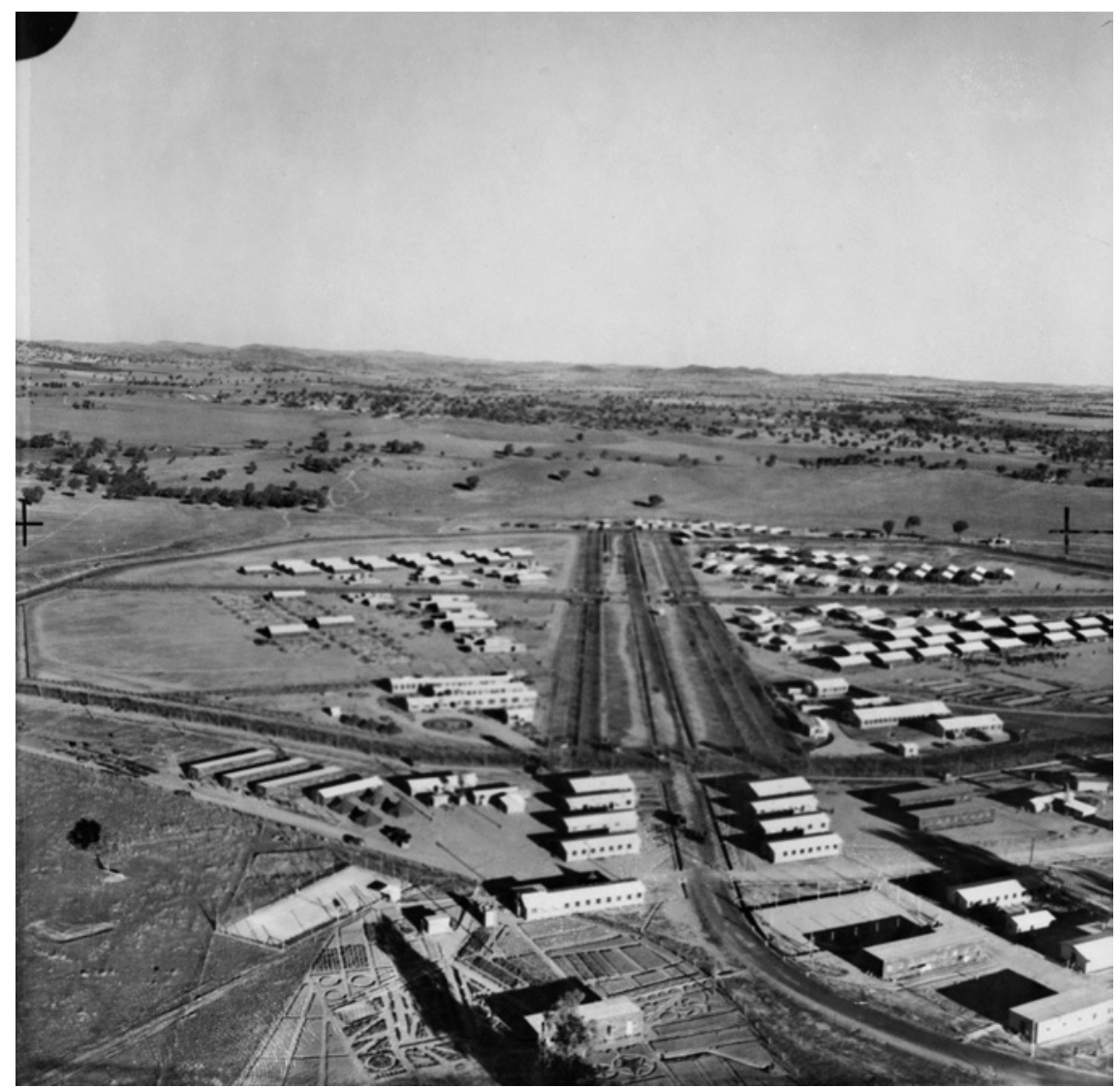

FI U UR 5 Cowra Prisoner of War Camp No. 12. Australian War Memorial Negative Number PO3160.002.

exile familiar to many Australians, these twentieth-century captives were essentially hostages of a global conflict. Consequently, the incident that propelled Cowra into national prominence and prompted the town's quest for post-war commemoration was exceptional for Australia, an example of citizens accepting responsibility for an otherwise disregarded history.

On 5 August 1944, a tragic misunderstanding led to an attempted mass breakout of 1,104 Japanese Pows from the camp at Cowra., resulting in 235 casualties (four guards and 231 Japanese Pows). ${ }^{38}$ It was the most serious wartime confrontation on Australian soil, and was caused by mutual cultural opacity

38 Steven Bullard, Blankets on the Wire: The Cowra Breakout and Its Aftermath (Canberra: Australian War Memorial 2006). 
and prejudices heightened by military propaganda. ${ }^{39}$ The deceased Pows were buried in an area adjacent to the Cowra general cemetery. From 1946-1947 onward the graves were tended by members of the Cowra sub-branch of the Returned Services League (RSL). ${ }^{40}$ However, Japan's recognition of its POWs and the Australian desire for mutual reconciliation would take a further two decades to surface. This was also true of Manzanar.

\section{Development of the Two Sites since World War II}

\section{$1 \quad$ Manzanar}

Preoccupied with the reconstruction of their lives and material well-being, during the post-wwiI era the Japanese American community in general repressed the memory of their incarceration-along with sentiments of humiliation and shame - until 1970, when the movement to memorialize and redress the event began to gain momentum, largely through Sansei (third-generation Japanese American) community activism. Encountering reluctance from their Nisei (second-generation American-born) parents to talk about their wartime experiences, Sansei initiated the Manzanar Pilgrimage as a way to engage the memory of the mass incarceration. Students involved in setting up Asian American studies programs decided to literally follow in the footsteps of two Issei ministers (first-generation Japanese immigrants), Sentoku Maeda and Shoichi Wakahiro, who had made the pilgrimage every year after the closure of the camps to ritually clean the graves in a ceremony known as ohakamairi, in honour of the people who had died at Manzanar. Choosing a bitterly cold and windy day, on 27 December 1969 the Sansei coordinated the pilgrimagewhich attracted over $15^{\circ}$ people-to clean the Manzanar Relocation Center cemetery and to repair its obelisk monument, known as the "Soul Consoling Tower" or "I RE I тO," built in 1943 by Manzanar's master stonemason Ryozo Kado (fig. 6). It remains one of the most visible monuments of the prison city, where every year a multifaith ohakamairi ceremony is held as part of the pilgrimage's annual program. ${ }^{41}$

39 Rumours that the rank and file might be relocated to another camp at Hay, New South Wales prompted a group vote for a mass breakout. Some 334 escapees were apprehended in the following week.

40 William Appleton, Rikai Means Understanding: A Guide to the Japanese War Cemetery (Cowra, NSw and Canberra: W.W. Appleton, 1998), 8-9.

41 Manzanar Committee, Reflections in Three Self-Guided Tours of Manzanar (Los Angeles: Manzanar Committee, 1998), 28; Manzanar Committee, "About Us," accessed 2 December 2016, http://www.manzanarcommittee.org/The_Manzanar_Committee/About_Us.html. The Manzanar Buddhist Association sponsored the obelisk's construction, soliciting 


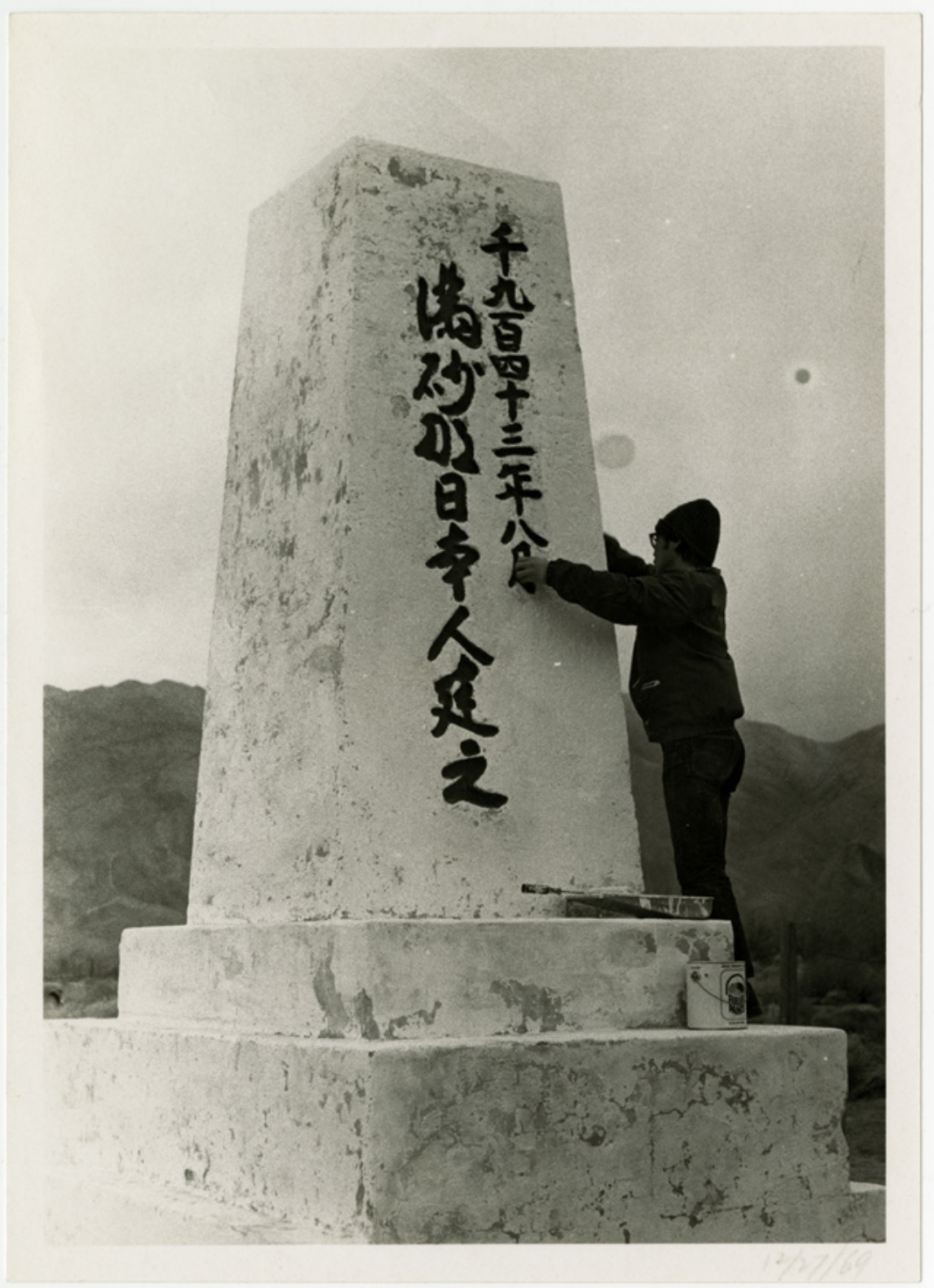

FIGURE 6 Repainting of the I REI TO, or "Soul Consoling Tower" at the first Manzanar Pilgrimage, 26 December 1969. Karl Yoneda Papers, UCLA Collection 1592, Box 13.

contributions of fifteen cents each to pay for its construction, and fifty Young Buddhist Association members volunteered to help with construction. See also Wendi Yamashita, "The Colonial and the Carceral: Building Relationships between Japanese Americans and Indigenous Groups in the Owens Valley," Amerasia 42, no. 1 (2016): 121-138. 
These commemorative modes and political movements spatially linked the resettled Japanese Americans in the urban metropolitan Los Angeles area and other former prisoners of Relocation Centers to the isolated Manzanar Relocation Center site. The Manzanar Committee members' efforts to draw attention to the site later merged with the movements for redress, a multigenerational effort to sponsor court cases and legislation to prevent any similar mass incarcerations from ever taking place again. President Ronald Reagan signed the bipartisan redress bill known as the Civil Liberties Act of 1988. The Manzanar National Historic Site was created in 1992 as part of the Us National Park Service (NPS), a moment that may be seen as part of the culmination of the redress movement. ${ }^{42}$ The Manzanar Committee now coordinates with the NPS in organizing an annual pilgrimage (fig. 7), with the mission to educate and counter racial discrimination and xenophobia in the United States, such as contemporary episodes of anti-Muslim hate crimes.

The Manzanar National Historic Site's Visiting Center is housed in the restored and rehabilitated auditorium, and the NPS now acts as custodian of the physical landscapes of the historic Manzanar Relocation Center. Their preservation plans and interpretive programs have been carefully worked out in a series of mandated NPS processes, with intensive community input but without the articulation of political goals. One of the most recent programs is Jeffery

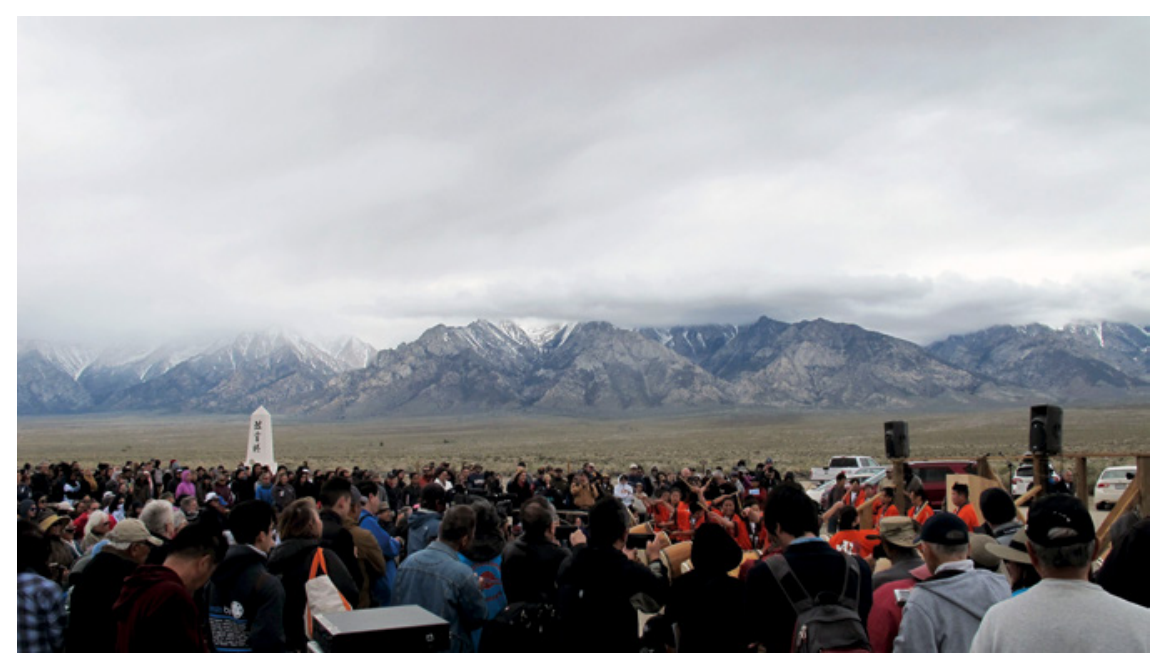

FIGURE 7 The annual Manzanar Pilgrimage (2016).

PHOTOGRAPH PROVIDED BY LYNNE HORIUCHI.

42 Roger Daniels, The Japanese American Cases: The Rule of Law in Time of War (Lawrence: University of Kansas Press, 2013), 159, 193. 


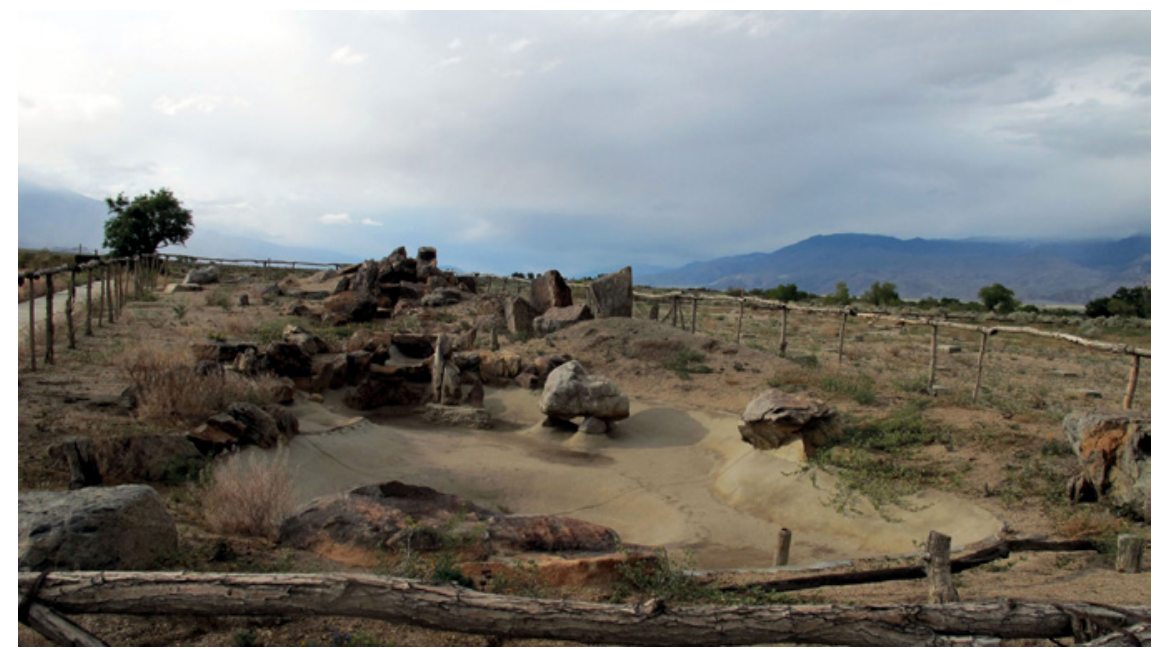

FIG URE 8 The Block 34 Mess Hall Garden, Manzanar National Historic Site (formerly Manzanar War Relocation Center), 2016. Inyo County, California, USA.

PHOTOGRAPH PROVIDED BY LYNNE HORIUCHI.

Burton's garden management plan. ${ }^{43}$ Following restoration and archaeological stabilization, this comprehensive plan proposes to draw in visitors and orient them to the prisoners' residential areas beyond the Visitor Center through the restoration and recreation of three Japanese-style gardens: a family barracks garden, a mess hall garden next to the block public facilities, and an elaborate Japanese community garden, also known as Merritt Park (fig. 8). Unlike the Cowra garden, which was designed by a professional Japanese landscape architect to subtly signify reconciliation with an enemy nation, the Manzanar gardens were originally designed by and for the prisoners-whose efforts might have been banned had they drawn the attention of the larger American public — and are now the object of their commemoration.

\section{$2 \quad$ Cowra}

Once diplomatic relations had improved between Japan and Australia an official cemetery was commissioned by the Japanese government in 1963, located side by side with the Australian War Cemetery at Cowra, an area used since the $1950{ }^{44}$ It included the graves of internees and Japanese servicemen and

43 Burton, Garden Management Plan, 4-9.

44 Ai Kobayashi and Bart Ziino, "Cowra Japanese War Cemetery," in Places of Pain and Shame: Dealing with "Difficult Heritage," ed. William Logan and Keir Reeves (London and New York: Routledge 2009), 100-112. 
airmen from other Australian sites. Japanese architect Shigeru Yura's design formed the nexus for subsequent reconciliatory strategies. The importance of human remains - including dissident pows — and of mutual respect within military culture is emphasized at Cowra, but it also touches Australian civilian sensibilities regarding family members lost in overseas conflicts. Such sentiments lie deep in the Australian psyche, a country where a million men and women (from a total population of about seven million) served during the Second World War. ${ }^{45}$ The process of reconciliation had to deal with Japan's coming to terms with its own POW histories, the Australian government's reluctance to address the history of the Cowra breakout, and Australia's own painful memories of internment under the Japanese. Together, the Cowra RSL sub-branch, the Cowra Municipal Council (from 1968), and the Cowra Tourist and Development Corporation chose to confront this history. The reconciliation process developed in phases related to the creation of the cemetery (1964), the Festival of International Understanding (1965), the Cowra Japanese Garden (1978-1979 and 1984-1986), and the heritage redevelopment of the Pow campsite from 1989, alongside the cultivation of a transnational relationship with a former POW campsite at Naoetsu (where Australians had been incarcerated) that has evolved into a "Peace and Friendship Agreement" with Joetsu City in Japan. ${ }^{46}$ From among these varied commemorative strategies, the Japanese Garden at Cowra - arguably an alien cultural tradition in Australia - has been welcomed and proved pivotal for heritage diplomacy and internationalization. The garden plays a leading role in representing the wartime history of Cowra (fig. 9). ${ }^{47}$

Gregory Missingham notes the choice of a Japanese-style garden outside Japan is not unusual, as there are around 690 publicly accessible gardens in similar styles located outside that nation's geography. ${ }^{48}$ These remain distinguishable from gardens associated with historic shrines, temples, or palaces within Japan and are shaped by multiple influences, including the topography and vegetation of the geographies to which they were introduced. While some of these gardens evolved alongside a nineteenth-century taste for chinoiserie, some draw on Japan's efforts at trade and cultural diplomacy, wherein gardens were featured in expositions and embassies before World War II. They

\footnotetext{
45 Australian War Memorial, "Second World War, 1939-45," https://www.awm.gov.au/ articles/second-world-war.

46 Joetsu City was founded in 1971 by the merger of Takada and Naoetsu.

47 The site was listed in the State Heritage Register of New South Wales in 1999.

48 Gregory Kenneth Missingham, "Japan 10 \pm , China 1: A First Attempt at Explaining the Numerical Discrepancy between Japanese-Style Gardens Outside Japan and Chinese-Style Gardens Outside China," Landscape Research 32, no. 2 (2007): 117.
} 


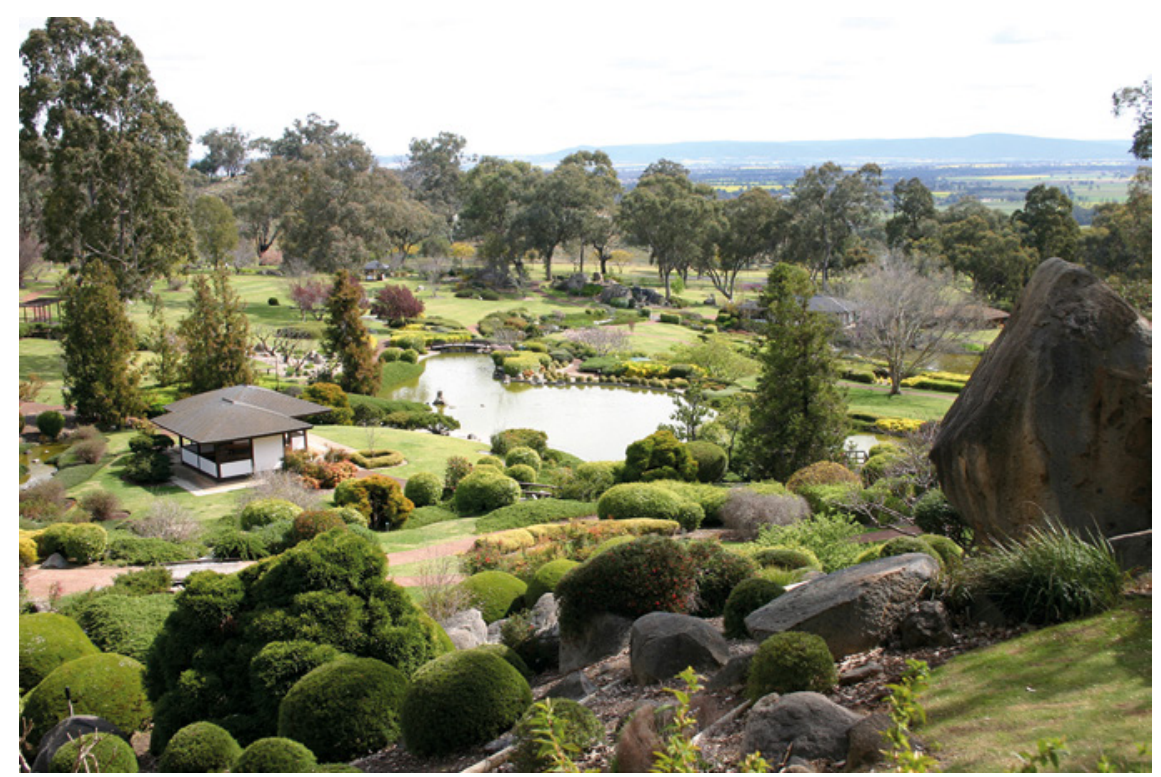

FIGURE 9 Cowra Japanese Garden at the former Cowra Prisoner of War Camp Site, 2014. Cowra, New South Wales, Australia. PHOTOGRAPH PROVIDED BY ANOMA PIERIS.

re-emerged as spaces for commemoration and transnational friendship in the post-war decades. ${ }^{49}$ As explained by Don Kibbler, President of the Cowra Tourism Development Corporation and a builder trained in architectural drawing, the idea for a garden was incidental, an effort at creating tourism interest during an economic downturn (for example, the gardens at No. 12 camp were built by Italian internees, not the Japanese Pows), but once the concept took hold a number of events reinforced it..$^{50} \mathrm{~A}$ key to its success was the support of a Japanese wool-manufacturing company desirous of investing in Cowra during the 1970s. Kibbler describes the efforts he made to garner enthusiasm for his project, carting around a model of a Japanese garden in the back of his station wagon until - with the support of the Department of Tourism, the Federal Government, the Japanese Chamber of Commerce and Industry, and Keidanren (the Japan Business Federation) — the first stage was initiated. ${ }^{51}$ Ken Nakajima,

49 Missingham, “Japan 10 \pm , China 1," 117, 128.

50 Don Kibbler and Tony Mooney interview with the authors, Cowra Nsw, Australia, 19 November 2016.

51 Don Kibbler, "Cowra-Japan Conversations," interview with Terry Colhoun for the Australia-Japan Research Project, 27 February 2003, accessed 6 December 2016, http:// ajrp.awm.gov.au/ajrp/ajrp2.nsf/trans/3 $\mathrm{D}_{3} \mathrm{~B} 8{ }_{3} \mathrm{~F}_{45} \mathrm{CF}_{2} \mathrm{C}_{4} \mathrm{BoCA} 256 \mathrm{D}_{5} 6001 \mathrm{~F} 25 \mathrm{E}_{1}$ ?open Document. 
a renowned Japanese landscape designer who had built Japanese gardens in Montreal and Moscow, was selected by competition. Nakajima conceived the garden as a piece of the Japanese homeland where the souls of deceased soldiers might find release. Its Japanese foliage and flora is complemented by Australian eucalypts, an invitation to deceased Australian comrades. The narrative of the garden spaces, with mountains and rivers running down to the ocean shore, is familiar to designers of Japanese strolling gardens, but was afforded a deeper meaning in relation to the prisoner breakout from the Cowra camp. The garden was conceived as a cathartic space for Japanese visitors seeking closure, and for locals striving to understand their role in that difficult history.

It is important to recognize that POw heritage commemoration at Cowra shares none of the national concerns or considerations raised in Manzanar with respect to culturally Japanese Australians. Political redress was not available to Japanese internees incarcerated in Australia; they were repatriated en masse. The lack of a resident Japanese community prompted a different engagement with this wartime carceral heritage, internationalizing Cowra's response. Cowra became a site for heritage diplomacy by exploring the potency of pow narratives for cultivating cultural tolerance in the Pacific region, which is fragmented by divisive national interests and post-war tensions. Although a shire of only 12,000 residents, largely of Anglo-European or WiradjuriAboriginal descent (with a few recent immigrants from Asia), the town features a Japanese garden, a World Peace Bell, a heritage site dedicated to the Pow camp, a Japanese war cemetery, and a memorial to camp guards, and is the most complex Australian site dealing with wartime incarceration histories.

\section{Commemorative Practices}

Although Pow incarceration is very different from civilian internment, diverse responses to issues of Japanese cultural identity reveal both the limitations of national perspectives and opportunities for internationalization that are seized or not, as the case may be. Japanese Americans have led a successful redress movement on the principles of liberal democracy by disassociating their communities from the Japanese militarism that damned them in the prejudiced eyes of wartime governments and public opinion. The spectre of Japan was an unsettling reality of the post-war period, reintroduced through high casualties of captives of the Japanese Imperial Army. ${ }^{52}$ Due to the post-war

$5^{2}$ Some 22,000 Australians were captured and 8,000 died during captivity (see Australian

War Memorial, "Stolen Years") and 29,813 Americans were captured (see "World War II 
repatriation of its internee population, Australia was not forced to confront its internal wartime injustices, reverting to its historic status as a penal colony by receiving Britain's prisoners, who considered Britain responsible for their incarceration (including the internment of Jewish families). The Australian government made no apologies and was not challenged by appeals for redress. Moreover, unlike the us, Australia incarcerated people from around thirty different nations associated with the Axis partnership while continuing to uphold the structural exclusions of colonial politics. Except for the case of Cowra, wartime internment appeared not to have created comparable domestic angst.

In contrast, Manzanar is an interesting case for demonstrating generational changes in interpretation and activism leading to redress in the us, focused almost completely on the abrogation of American civil rights with the goal of recognizing the right of every American to full citizenship. Greg Robinson, one of the pre-eminent chroniclers of EO 9066, has noted that the fixed spatial and national boundaries of its interpretation remains a troubling problem even as the mass incarceration - annually remembered on the anniversary of the issuance of the executive order-has remained an important civil liberties case study, and, as the number of sites restored and commemorated has grown, as a point of reference for all ethnically diverse groups of Americans.

The disciplines of architecture and urban planning are ideal departure points from which to explore conditions and movements within internment camps in order to understand the impacts of mass incarceration. Scholars of architectural and urban history are beginning to disentangle themselves from the formal aesthetic analyses structured by their professional disciplines, and including not only interdisciplinary approaches but also the heterogeneous contexts in which city-building takes place in order to understand the responses of builders and inhabitants to such spaces as critiques of everyday life, which can be seen in the case of the Manzanar gardens.

Social justice issues are central to the interpretation and commemoration of these sites, tackling issues of national belonging that may seem more apparent in documentary, historical, or theoretical representations of mass incarceration. Commemoration continues to be celebrated at the Manzanar National Historic Site through the power of its physical presence and through community participation, the latter principally in the annual Manzanar Pilgrimagean expression and extension of the community activism that successfully lobbied for the preservation of the Manzanar Relocation Center as a historic site.

Prisoners of the Japanese," National Archives and Records Administration Data Files, 2007 Update, ca. 1941-1945, Series from Collection ADBC: Records of the American Defenders of Bataan and Corregidor, https://aad.archives.gov/aad/series-description.jsp?s=4277). 
The commemorative task at Cowra was not solely of building internal racial tolerance in a town with a military history, but of making a hated enemy into a trading partner and potential ally. These political shifts and regional partnerships underscored post-war introspection and informed representations of the past. Efforts made by private citizens, tourism bodies, and RSL members in concert with Japanese governmental and private organizations were the mainstays of this process.

Today, the Cowra Japanese Garden is neither a museum nor a memorial; these functions have been diverted to other spaces in the township. No physical trace of the breakout story is visible in its fashioning. Its force is its uncanny beauty in the semi-arid, rock-strewn landscape of Cowra, and its cultural distinction as a gift, in part, from Japan. But this beauty cannot convey the garden's deeper history without interpretive input. Its designation as a peace precinct and its chorus of supporting spaces, identified by staff at the Cowra Visitor Centre, forestall its conflation with other touristic venues. The resilience of this site is largely dependent on whether the nation will come on board to recognize these histories, but at the moment tales of heroism or incarceration in Asia preoccupy Australians.

The discursive incongruities and ethical fault lines in these separate commemorative strategies emerge through the comparison of the Us and Australian cases, which are arguably very similar in their settler composition, attitudes to race, and tolerance or intolerance of immigration when compared to the major belligerents of the Second World War-Britain, Germany, the Soviet Union, and Japan. While the provocations for establishing the camps are similar, their form, configuration, population, and political significance appear radically different in these two contexts. This is also true of how their geopolitics are mobilized for redress or reconciliation at a national or international level. American scholars are focused on the health of nation, while Australians concentrate on their survival in the Asia Pacific. Differing deployments of affective materialities in each of these scenarios-most evident in their Japanese garden spaces-clearly reflects their divergence. Comparative analyses such as this one force us to recognize how scholarship on this topic is embedded in each nation's respective field of sovereignty, invariably shaped by their separate engagements in the Pacific War. Intellectual convergence across these separate fields exposes other gaps and silences in scholarship as well as in legislative and commemorative efforts, with mutual benefits.

\section{Lynne Horiuchi}

is an architectural historian and author of Dislocations and Relocations: The Planning, Design, and Construction of Japanese American Concentration Camps (University of 
Washington Press, 2018), and has co-edited (with Tanu Sankalia) a collection of multidisciplinary essays, Urban Reinventions: San Francisco's Treasure Island (University of Hawai'i Press, 2017).

\section{Anoma Pieris}

is an associate professor in the Faculty of Architecture Building and Planning at the Melbourne School of Design. She has published extensively on architectural history, including Assembling the Centre: Architecture for Indigenous Cultures-Australia and Beyond (Routledge, 2015), co-authored with Janet McGaw.

\section{References}

Agamben, Giorgio. State of Exception. Chicago: University of Chicago Press, 2005. Appleton, William. Rikai Means Understanding: A Guide to the Japanese War Cemetery. Cowra, Nsw, and Canberra: W.W. Appleton, 1998.

Apthorpe, Graham. A Town at War: Stories from Cowra in World War II. Cowra, NSw: G. Apthorpe, 2008.

Australian Government Federal Register of Legislation. "National Security Act 1939." 9 September 1939. https://www.legislation.gov.au/Details/C1939Aooo15.

Australian War Memorial. "Enlistment Statistics, Second World War." https://www .awm.gov.au/encyclopedia/enlistment/ww2.

Australian War Memorial. "Second World War, 1939-45." https://www.awm.gov.au/ articles/second-world-war.

Australian War Memorial. "Stolen Years: Australian Prisoners of War." https://www .awm.gov.au/exhibitions/stolenyears/ww2/japan.

Azuma, Eiichiro. Between Two Empires: Race, History, and Transnationalism in Japanese America. New York: Oxford University Press, 2005.

Bullard, Steven. Blankets on the Wire: The Cowra Breakout and Its Aftermath. Canberra: Australian War Memorial, 2006.

Burton, Jeffery. Garden Management Plan: Gardens and Gardeners at Manzanar, Manzanar National Historic Site, California. Independence, CA: National Park Service, us Department of the Interior, Manzanar National Historic Site, 2015.

Burton, Jeffery F., Mary M. Farrell, Florence B. Lord, and Richard Lord. Confinement and Ethnicity: An Overview of World War II Japanese American Relocation Sites. Tucson: Western Archaeological Center, 2000.

Cohen, Jean-Louis. Architecture in Uniform: Designing and Building for the Second World War. Paris and Montreal: The Canadian Centre for Architecture, 2011.

Constant, Caroline. The Modern Architectural Landscape. Minneapolis: University of Minnesota Press, 2012. 
Crysler, C. Greig, Stephen Cairns, and Hilde Heynen (eds). The SAGE Handbook of Architectural Theory. London: SAGE Publications Inc., 2012.

Daniels, Roger. The Japanese American Cases: The Rule of Law in Time of War. Lawrence, Kansas: University of Kansas Press, 2013.

Foucault Michel. Discipline and Punish: The Birth of the Prison. Translated by Alan Sheridan. New York: Pantheon Books, 1977.

Foucault Michel. Power/Knowledge: Selected Interviews and Other Writings, 1972-1977. Edited and translated by Colin Gordon. New York: Pantheon Books, 1980.

Fujitani, Takashi, Geoffrey M. White, and Lisa Yoneyama (eds). Perilous Memories: The Asia-Pacific War(s). Durham: Duke University Press, 2001.

Gesensway, Deborah, and Mindy Roseman. Beyond Words: Images from America's Concentration Camps. Ithaca: Cornell University Press, 1987.

Gudridge, Patrick O. "Remember Endo?" Harvard Law Review 116 (2003): 19331970.

Hammond, Joyce. Walls of Wire: Tatura, Rushworth, Murchison. Rushworth, Victoria: Joyce Hammond, 1990.

Helphand, Kenneth I. Defiant Gardens: Making Gardens in Wartime. San Antonio: Trinity University Press, 2006.

Horiuchi, Lynne. "Architects at War: Designing Prison Cities for Japanese American Communities." In Diversity and Design: Understanding the Hidden Consequences, edited by Beth Tauke, Korydon Smith, and Charles Davis, 101-117. New York: Routledge, 2016.

Horiuchi, Lynne. "Dislocations and Relocations: The Built Environments of Japanese American Internment." Ph.D dissertation, University of California, Santa Barbara, 2005.

Kashima, Tetsuden. Judgment Without Trial: Japanese American Imprisonment During World War II. Seattle: University of Washington Press, 2003.

Kibbler, Don. "Cowra-Japan Conversations." Interview with Terry Colhoun for the Australia-Japan Research Project. 27 February 2003. Accessed 6 December 2016. http://ajrp.awm.gov.au/ajrp/ajrp2.nsf/trans/3 $\mathrm{D}_{3} \mathrm{~B}_{3} \mathrm{~F}_{45} \mathrm{CF}_{2} \mathrm{C}_{4} \mathrm{BoCA}_{25} \mathrm{D}_{5} 6001 \mathrm{~F} 25$ E1?openDocument.

Kobayashi, Ai, and Bart Ziino. "Cowra Japanese War Cemetery." In Places of Pain and Shame: Dealing with "Difficult Heritage," edited by William Logan and Keir Reeves, 100-112. London and New York: Routledge, 2009.

Leong, Karen J., and Myla Vicenti Carpio. “Carceral States." Special issue. Amerasia 42, no. 1 (2016).

Logan, William, and Keir Reeves. Places of Pain and Shame: Dealing with "Difficult Heritage." London and New York: Routledge, 2009.

Lu, Duanfang (ed). Third World Modernism: Architecture, Development and Identity. London and New York: Routledge, 2011. 
Lye, Colleen. America's Asia: Racial Form and American Literature, 1893-1945. Princeton: Princeton University Press, 2005.

Manzanar Committee. Reflections: In Three Self-Guided Tours of Manzanar. Los Angeles: Manzanar Committee, 1998.

Missingham, Gregory Kenneth. "Japan 10 \pm , China 1: A First Attempt at Explaining the Numerical Discrepancy between Japanese-Style Gardens Outside Japan and Chinese-Style Gardens Outside China." Landscape Research 32, no. 2 (2007):117-146.

Moran, Dominique. Carceral Geography: Spaces and Practices of Incarceration. Farnham and Surrey: Ashgate Publishing, 2015.

Nagata, Yuriko. Unwanted Aliens: Japanese Internment in Australia. Brisbane: University of Queensland Press, 1996.

National Archives of Australia. Canberra: A2671, 157/1940 PART 1, War Cabinet Agendum-No. 157/1940-Prisoners of War and internees from abroad.

National Archives of Australia."Wartime Internment Camps in Australia." Database. http://naa.gov.au/collection/snapshots/internment-camps/index.aspx\#sectionı.

National Archives of Australia. "World War I Internee, Alien and pow Records held in Adelaide-Fact sheet 106.” Database. http://naa.gov.au/collection/fact-sheets/ fsio6.aspx.

New South Wales Office of Environment and Heritage. "Cowra Prisoner of War Camp Site." Database number: 5045173. File number: S9o/oo661; S91/o6355 \& HC870813. http://www.environment.nsw.gov.au/heritageapp/ViewHeritageItemDetails. aspx? ID $=5045173$.

"Personal Justice Denied: Report of the Commission on Wartime Relocation and Internment of Civilians." United States Commission on Wartime, Relocation, and Internment of Civilians (CWRIC). Seattle: University of Washington Press; Washington, DC: Civil Liberties Public Education Fund, 1997.

Rajagopalan, Mrinalini, and Madhuri Desai (eds). Colonial Frames, Nationalist Histories: Imperial Legacies, Architecture, and Modernity. Farnham: Ashgate Publishing, 2012.

Robinson, Greg. A Tragedy of Democracy: Japanese Confinement in North America. New York: Columbia University Press, 2009.

Robinson, Greg, and Toni Robinson. "Korematsu' and Beyond: Japanese Americans and the Origins of Strict Scrutiny." Law and Contemporary Problems 68, no. 2 (2005): 29-55.

Sand, Jordan. "Reconfiguring Pacific History: Reflections from the Pacific Empires Working Group." Amerasia Journal 42, no. 3 (2016): 1-41.

Saunders, Kay, and Roger Daniels (eds). Alien Justice: Wartime Internment in Australia and North America. Brisbane: University of Queensland Press, 2000.

Sen, Arijit, and Jennifer Johung (eds). Landscapes of Mobility: Culture, Politics and Placemaking. London and New York: Routledge, 2013. 
"Suggested Resettlement or Work Projects." April 1942. Box 1, Records of the Bureau of Agriculture Economics, Record Group 83. National Archives and Records Administration at San Francisco, San Bruno, CA, USA.

"Summary Report on Center Requested by Dr. Carter, 24 July 1942." Japanese Evacuation and Resettlement Study from Bancroft Library, Drawer Manz I, Folder "Official Documents." Eastern California Museum, Independence, CA, USA.

Takamura, Kango. Saturday Afternoon Looking South from Block 8. May 1943. University of California Los Angeles Special Collections, Collection 433, Box 1 Manzanar, F.16. Los Angeles, CA, USA.

Tauke, Beth, Korydon Smith, and Charles Davis (eds). Diversity in Design: Understanding Hidden Consequences. Abingdon and New York: Routledge, 2016.

Tracey, Jennifer Lambert, and Michael MacLellan Tracey. "Archaeological Assessment of the Site of Prisoner of War Camp 12, Cowra, Nsw. October 2003." Canberra: Heritage Archaeology, 2003.

Unrau, Harlan D. The Evacuation and Relocation of Persons of Japanese Ancestry During World War II: A Historical Study of the Manzanar War Relocation Center. [Denver, Colo.?]: Us Department of the Interior, National Park Service, 1996.

Upton, Dell. Another City: Urban Life and Urban Spaces in the New American Republic. New Haven: Yale University Press, 2008.

Upton, Dell, and John Michael Vlach (eds). Common Places: Readings in American Vernacular Architecture. Athens: University of Georgia Press, 1986.

Wilkins, Craig L. The Aesthetics of Equity: Notes on Race, Space, Architecture, and Music. Minneapolis: University of Minnesota Press, 2007.

"World War II Prisoners of the Japanese." National Archives and Records Administration Data Files, 2007 Update, ca. 1941-1945. Series from Collection ADBC: Records of the American Defenders of Bataan and Corregidor. https://aad.archives.gov/aad/ series-description.jsp?s=4277.

Yamashita, Wendi. "The Colonial and the Carceral: Building Relationships between Japanese Americans and Indigenous Groups in the Owens Valley." Amerasia 42, no. 1 (2016): 121-138. 